\title{
The Electrification of Tramways in Ostrava in 1900-1901
}

\author{
Michaela Závodná \\ Dept. of History, Centre for Economic and Social History, Faculty of Arts, University in Ostrava, Reální 5, 70103 \\ Ostrava, Czech Republic \\ Corresponding author: michaelazavodna@seznam.cz
}

\begin{abstract}
This paper focuses on the electrification of tramways in Ostrava in 1900-1901. As the administrative, economic and cultural centre of an evolving industrial agglomeration, Ostrava had specific transportation requirements. Tram electrification was in response to these requirements. Two private companies, Brünner Lokaleisenbahngesellschaft and Ganz 8 Comp.,( Mährisch-Ostrauer Elektrizitäts-Aktien-Gesellschaft) negotiated an agreement. The first part of this paper deals with technical aspects of electrification the change-over from steam power to electric power, while the second section analyses the dealings between these private companies, subsequent municipalization and the involvement of the municipal self-government of Moravská Ostrava.
\end{abstract}

Keywords: history of technology, tramway, electrification, municipalization, Ostrava.

\section{Introduction}

Electricity and trams are two sides of the same coin. Electrification was an major economic and sociospatial phenomenon. Electric trams played a significant role as consumers of the electricity produced by the central power plant. Electrification of means of transport provided new opportunities for the growth of cities. In this context, electrification was an essential step toward modernization of society. Tramway electrification was in most cases accompanied by municipalization. This meant that tramways were considered as a monopoly of public necessity: "And, as such, should not be used to put large dividends into the pockets of shareholders." [1, p. 172]

Tramways developed not as a money-making private enterprise, but for the benefit of the public. The development of the tramway network was seen as an act of social policy enabling both urban planning and important changes in the social structure of cities.

\section{The electrification of tramways in Ostrava in 1900-1901}

Electrification did not automatically mean municipalization, however, and there was no clear-cut connection between setting up power stations and operating electric trams. The Ostrava-Karviná mining district provides an example of how electric-powered trams became established.

Around 1900, Moravská Ostrava was shaping up and became the administrative, economic and cultural centre of the evolving industrial agglomeration.
Its mining and industrial history provided specific conditions for the development and the expansion of local public mass transport.

Beginning in 1894, the tramway transport network in Ostrava was built up by the Brünner Lokaleisenbahngesellschaft transport company. On August 18th, 1894, the first steam-powered line was opened between Přívoz, Moravská Ostrava and Vítkovice. Goods transport began at the same time. In 1899, a new line was opened to Lhotka (present-day Mariánské Hory). Until 1901, all these lines were operated by steam locomotives. The lines were used by 348243 passengers in 1894. Five years later, the number of passengers had increased to 1480980 [2, p. 7].

The transport company therefore established a new timetable, with trams running at 20-minute intervals. Problems soon arose with this new tram system. Neither the vehicles nor the rails were robust enough for the rising traffic frequency. In addition, steam locomotives required large amounts of coke, and the operating costs kept rising. The transport company tried to deal with this negative trend. First, the number of trams was reduced from 16 to 9 , and then the frequency of the service was reduced. The new timetable scheduled 30 minutes between trams [3]. However, it became clear that the operation needed new technical developments, and that it was time to redevelop mass transport in the district of Ostrava. The board of governors of Brünner Lokaleisenbahngesellschaft began to consider replacing uneconomical and expensive steam by electricity. The company contacted several electricity companies, and finally selected Österreichische Schuckert-Werke. The first contacts between Österreichische Schuckert-Werke and Brünner Lokaleisenbahngesellschaft were tentative. The transport 


\begin{tabular}{cc}
\hline Line & Number \\
\hline $\begin{array}{c}\text { Railway station Moravská } \\
\text { Ostrava - Downtown }\end{array}$ & 4 \\
\hline Moravská Ostrava - Vítkovice & 5 \\
\hline Moravská Ostrava - Lhotka & 2 \\
\hline Reserve & 4 \\
\hline
\end{tabular}

Table 1: Number of electric locomotives bought in 1900.

company asked if Schuckert-Werke would be able to make detailed plans for futur electrification of trams in Ostrava. The total investment was estimated at 700 000-800 000 Kronen [3]. The cost of electrification rose to 1120000 Kronen, and to 1300000 Kronen, in subsequent negotiations [5], [7]. Brünner Lokaleisenbahngesellschaft would cover this investment by issuing 5350 new shares at 200 Kronen. The rest would be paid from the reserve fund of the transport company [8]. A specific plan for electrification was made by Österreichische Schuckert-Werke, and was debated by state offices between July 9th-11th, 1900 $[2$, p. 7]. Electric trams were to be put into operation in Ostrava in October 1900 [5], [7].

However, Österreichische Schuckert-Werke had many problems with the materials that were required and with installing the overhead wires. The date for launching the electric trams was postponed several times. The works were completed in March 1901. The police and technical inspection was carried out on April 4th, 1901. The next day, regular electric transport services were started [2, p. 8], [5], [7], [8].

The transport company sent two of its employees, chief operating officer Reinhart and foreman Fösl, to Liberec for an internship. At the same time, Brünner Lokaleisenbahngesellschaft bought 15 new electric locomotives [5], [7], see Tab. 1.

Only personal transport was electrified. Steam locomotives continued to operate for freight transport . At the same time, the transport company had to solve problems with electricity supply. Brünner Lokaleisenbahngesellchaft originally planned to have its own power station [4]. Later, this idea was abandoned for two reasons. The first reason was the extremely high costs. As Österreichische Schuckert-Werke wrote in its report, the price per $1 \mathrm{kWh}$ was be estimated at 20-24 Heller [5], [7]. The second reason was more substantial. The central power plant in Moravská Ostrava, owned by Ganz $\&$ Comp., had come into operation in 1897. On May 31st, 1897, this company and the municipal self-governments of Moravská Ostrava closed a deal. Ganz \& Comp. was given an exclusive right to use public property (streets, squares, etc.) for the production and delivery of electricity in the

\begin{tabular}{cc}
\hline Quantity & Price per kWh \\
\hline$<350000 \mathrm{kWh}$ & 16 heller \\
\hline $351000-700000 \mathrm{kWh}$ & 14 heller \\
\hline$>700000 \mathrm{kWh}$ & 12 heller \\
\hline
\end{tabular}

Table 2: Prices of electricity negotiated by Brünner Lokaleisenbahngesellschaft and Ganz $\&$ Comp. in 1900 .

district of Moravská Ostrava [11, p. 143]. Brünner Lokaleisenbahngesellschaft was able to buy a plot of land and built its own power station there, but it could not use the public streets for delivering electricity. The transport company also considered that this agreement between Moravská Ostrava and Ganz $\&$ Comp. infringed its own exclusive right to use public property [4] . In the end, the transport company and the electricity company negotiated an agreement. These negotiations led to an agreement on prices for electricity for the requirements of the tramway lines from Přívoz to Moravská Ostrava, Vítkovice and Lhotka [5], [6], [7], [12, p. 528], see Tab. 2.

The same prices were also used in the tram network in Brno. A fifteen-year trade agreement between Brünner Lokaleisenbahngesellschaft and MährischOstrauer Elektrizitäts-Aktien-Gesellschaft (the legal successor to Ganz \& Comp. from May 1900) was signed on July 21st, 1900. Electricity was to be supplied daily from 5.00 a.m. to 11 p.m. The $2000 \mathrm{~V}$ alternating current was transformed to direct current by three $510 \mathrm{HP}$ converters. From October to March, the amperagethe power was to be delivered at $200 \mathrm{~kW}$, and from March to October at $400 \mathrm{~kW}$ [9], [10]. Electric trams could not have been operated in Ostrava without these negotiations and agreements.

\section{Municipal involvement}

Although the municipal authorities knew about the tram electrification, because the municipality itself was a shareholder in Mährisch-Ostrauer ElektrizitätsAktien-Gesellschaft and some members of the municipal self-government held shares in Brünner Lokaleisenbahngesellschaft, the municipal self-government itself did not attempt to municipalize the network of electric tramways in Ostrava. Electrification of the tram network was an enterprise undertaken by two independent, private companies. The main impulse was the rising cost of operating steam-powered trams. Brünner Lokaleisenbahngesellschaft was motivated mainly by economic considerations, rather than by social considerations, to replace steam by electricity. 


\section{References}

[1] J. P. McKay. Tramways and Trolleys. The rise of urban mass transport in Europe. Princeton 1976.

[2] M. Eber. Die Entwicklung des Verkehrs in und um Mährisch Ostrau. Mährisch Ostrau 1913.

[3] $\mathrm{AMO}^{1}$, fund $\mathrm{SMMD}^{2}$, inv. no. 13. Zápisy ze zasedání správní rady společnosti (Board of governors proceedings). Proceedings for May 17th, 1899 .

[4] AMO, fund SMMD, inv. no. 13. Proceedings for October 17th, 1899.

[5] AMO, fund SMMD, inv. no. 13. Proceedings for March 10th, 1900.

[6] AMO, fund SMMD, inv. no. 9. XIV. annual general meeting proceedings for April 21st, 1900.
[7] AMO, fund SMMD, inv. no. 13. Proceedings for November 5th, 1900.

[8] AMO, fund SMMD, inv. no. 9. XV. Annual general meeting proceedings for April 20th, 1901.

[9] AMO, fund SMMD, inv. no. 292, box no. 39.

[10] AMO, fund Archiv města Moravská Ostrava ${ }^{3}$, Nová registratura ${ }^{4}$, box no. 531 .

[11] P. Kladiwa. Obecní výbor Moravské Ostravy 1850-1913. Komunální samospráva prümyslového města a její predstavitelé. Ostrava 2004.

[12] Gemeindeverwaltung und Gemeinde-Statistik der Landeshauptstadt Brünn. Bericht des Bürgermeisters dr. August Ritter v. Wieser für das Jahr 1898. Brünn 1899.

\footnotetext{
${ }^{1}$ Archiv města Ostravy, Archiv of Ostrava.

${ }^{2}$ Společnost moravských místních drah.
}

\footnotetext{
${ }^{3}$ Archive Fund of the City of Moravská Ostrava/

${ }^{4}$ New Register Office.
} 